\title{
PENGARUH WAKTU BELAJAR TERHADAP KEMAMPUAN KONEKSI MATEMATIKA DENGAN MENGONTROL KEMAMPUAN AWAL
}

\section{THE EFFECT OF LEARNING TIME AGAINST MATHEMATICAL CONNECTION ABILITY BY CONTROLING INITIAL ABILITY}

\author{
Ihwan Zulkarnain dan Muhamad Farhan \\ Program Studi Pendidikan Matematika, FMIPAUniversitas Indraprasta PGRI Jakarta, Jakarta, Indonesia \\ Email: Irvan_arie@yahoo.com
}

Diterima: 4 Juli 2019. Disetujui: 9 Juli 2019. Dipublikasikan: 2 Maret 2020

\begin{abstract}
Abstrak: Tujuan dari penelitian ini adalah untuk membantu meningkatkan kemampuan koneksi matematika siswa yang selama ini berbeda di setiap kelasnya, hal ini lantaran perbedaan waktu belajar antara pagi dan siang hari yang dianggap sangat berpengaruh terutama ketika sedang belajar dan mengerjakan soal matematika. Metode penelitian yang digunakan adalah Metode penelitian yang digunakan adalah metode eksperimen dengan membandingkan kelas eksperimen sebanyak 20 siswa dan kelas kontrol sebanyak 20 siswa. Penelitian dilaksanakan di SMA Bogor Center School Bogor tahun ajaran 2017/2018 kelas XI dengan jurusan IPA. Teknik pengambilan sampel dalam penelitian didasarkan pada teknik multi stage random sampling, sebanyak 3 stage (tahap), yaitu : tahap pertama memilih kelompok belajar (pada penelitian ini, yang dipilih kelompok belajar reguler), tahap kedua memilih kelas (rombongan belajar), dan tahap ketiga memilih subjek penelitian (siswa). Pengumpulan instrumen yang digunakan untuk pengumpulan data peneliti adalah tes sebanyak 10 soal Uraian. Teknik analisis data menggunakan uji-t. Berdasarkan perhitungan didapat 0,032 <0,05, sehingga disimpulkan bahwa kemampuan koneksi matematika siswa yang belajar di pagi hari secara signifikan lebih tinggi dari pada siswa yang belajar di siang hari, setelah mengontrol kemampuan awal siswa.
\end{abstract}

Kata Kunci: Waktu Belajar, Koneksi Matematika, Kemampuan Awal.

\begin{abstract}
The purpose of this study is to help improve the mathematical connection skills of students who have been different in each class, this is due to differences in learning time between morning and afternoon which is considered very influential especially when studying and working on math problems. The research method used is the research method used is the experimental method by comparing the experimental class as many as 20 students and the control class as many as 20 students. The study was conducted at Senior High of Bogor Center School in the 2017/2018 academic year class XI with a science major. The sampling technique in the study was based on a multi stage random sampling technique, as many as 3 stages (stages), namely: the first stage of choosing a study group (in this study, the regular study group), the second stage choosing the class (study group), and stage the third chooses research subjects (students). The collection of instruments used for data collection of researchers is a test of 10 questions about the description. The data analysis technique uses the t-test. Based on calculations obtained $0.032<0.05$, so it was concluded that the mathematical connection ability of students who study in the morning is significantly higher than students who study during the day, after controlling for students' initial abilities.
\end{abstract}

Keywords: Learning Time, Mathematical Connection, Early Ability.

\section{PENDAHULUAN}

Proses pembelajaran merupakan aktivitas yang paling utama di dalam sekolah. Pembelajaran matematika merupakan salah suatu proses belajar mengajar yang terdiri dari kombinasi dua aspek, yaitu belajar yang dilakukan oleh siswa dan mengajar yang dilakukan oleh guru sebagai pengajar (pendidik). Belajar tertuju kepada apa yang harus dilakukan oleh seseorang sebagai subjek yang menerima pelajaran, sedangkan mengajar berorientasi pada apa yang harus dilakukan oleh guru sebagai pemberi pelajaran. Kedua aspek ini akan berkolaborasi secara terpadu menjadi suatu kegiatan pada saat terjadi interaksi antara guru dengan siswa, serta antara siswa dengan siswa di saat pembelajaran matematika sedang berlangsung.
Proses pembelajaran matematika bukan hanya sekedar transfer ilmu dari guru kepada siswa, melainkan suatu proses yang dikondisikan atau diupayakan oleh guru, sehingga siswa aktif dengan berbagai cara untuk mengkonstruksi atau membangun sendiri pengetahuannya, serta terjadi interaksi dan negosiasi antara guru dengan siswa serta antara siswa dengan siswa [1]. Pembelajaran matematika yang dimaksud adalah pembelajaran matematika yang bermakna sehingga siswa mendapat sesuatu yang bermanfaat bagi dirinya setelah selesai pembelajaran.

Kondisi belajar yang aktif, kreatif, efektif dan menyenangkan bagi siswa dapat tercipta dengan menerapkan pendekatan pembelajaran yang tepat [2]. Untuk mencapai harapan tersebut, seorang guru 
harus terampil dalam memilih pendekatan yang tepat dengan pokok bahasan yang disajikan dan karakteristik siswa. Guru yang berpengalaman akan memiliki kemampuan yang lebih baik dalam memilih pembelajaran yang sesuai dengan pokok bahasan yang akan diajarkan dan kebutuhan siswa.

Namun, berdasarkan pengalaman peneliti dilapangan, ada beberapa faktor lain yang mempengaruhi kinerja siswa dalam memahami pelajaran matematika dikelas yakni perbedaan waktu belajar. Belajar pada pagi hari lebih efektif daripada belajar pada waktu-waktu lainnya. Hal ini dikarenakan pada pagi hari kondisi jasmani dan rohani siswa masih segar dan memori otak masih kosong, sehingga mudah menyerap materi yang diajarkan [3]. Ditambah lagi sebelum masuk ke kelas masing-masing, para siswa/siswi khususnya yang beragama islam melaksanakan sholah dhuha terlebih dahulu. Waktu pembelajaran merupakan waktu terjadinya proses belajar-mengajar di sekolah, waktu belajar di sekolah dapat pagi, siang maupun sore [4]. Demikian pula kondisi waktu pembelajaran di sekolah. Waktu pembelajaran di kelas dapat mempengaruhi proses belajar siswa.

Selain hal di atas, Kemampuan koneksi matematika merupakan hal yang penting untuk siswa maupun guru pengajar dalam proses di dalam kelas. Siswa yang terbiasa belajar di semua waktu (pagi maupun siang) tidak dengan sendirinya pintar dalam mengkoneksikan matematika. Dalam sebuah penelitian ditemukan bahwa siswa sering mendaftar konsep-konsep perbab yang terkait dengan masalah riil, tetapi hanya sedikit siswa yang mampu menjelaskan mengapa konsep tersebut digunakan dalam aplikasi itu [5]. Dengan demikian kemampuan koneksi perlu dilatihkan kepada siswa sekolah. Apabila siswa mampu mengkaitkan ide-ide matematika maka pemahaman matematikanya akan semakin dalam dan bertahan lama karena mereka mampu melihat keterkaitan antar topik dalam matematika, dengan konteks selain matematika, dan dengan pengalaman hidup sehari-hari [6]. Bahkan koneksi matematika sekarang dengan matematika jaman dahulu, misalkan dengan matematika zaman Yunani, dapat meningkatkan pembelajaran matematika dan menambah motivasi siswa [7].

Dalam pembelajaran di kelas, koneksi matematika antar konsep-konsep dalam matematika sebaiknya didiskusikan oleh siswa, pengkoneksian antar ide matematika yang diajarkan secara eksplisit oleh guru tidak membuat siswa memahaminya secara bermakna, Hiebert dan Carpenter [5]. Pembelajaran yang sesuai adalah tidak dengan calk and talk saja namun siswa harus aktif melakukan koneksi sendiri. Dalam hal ini siswa tidak boleh dipandang sebagai passive receivers of ready-made, namun sebaliknya siswa dianggap sebagai individu aktif yang mampu mengembangkan potensi matematikanya sendiri.
Dalam proses pembelajaran banyak dijumpai masalah yang dihadapi guru maupun siswa, baik di lingkungan sekolah maupun di luar sekolah. Masalah pendidikan dan pembelajaran meliputi kesulitan dan hambatan yang dihadapi siswa dalam rangka perkembangan belajarnya, sehingga guru diharapkan dapat mengarahkan siswa dalam menghadapi masalah-masalah tersebut agar hasil belajarnya optimal. Hambatan dalam belajar tercermin dalam beberapa gejala masalah, seperti hasil dan prestasi belajar rendah, kurang atau tidak adanya motivasi belajar, kebiasaan kurang baik dalam belajar, sikap yang kurang baik terhadap pelajaran, guru, atau pun sekolah.

Setiap gejala masalah ada yang melatar belakangi, demikian juga dengan masalah belajar. Misalnya prestasi belajar rendah dapat dilatar belakangi oleh kecerdasan yang rendah, kurangnya motivasi belajar, kebiasaaan belajar yang kurang baik, gangguan kesehatan, kurangnya sarana belajar, kondisi keluarga kurang mendukung, guru mengajar kurang sesuai, materi pelajaran yang sulit, kondisi sekolah tidak baik, dan sebagainya [4]. Keseluruhan faktor-faktor yang melatarbelakangi masalah belajar ini, dapat digolongkan kepada faktor internal dan faktor eksternal. Faktor internal mencakup segi intelektual seperti kecerdasan, bakat, minat, dan hasil belajar; segi emosional seperti motif, sikap, perasaan, keinginan, kemauan, kondisi kesehatan fisik serta mental, dan sebagainya. Faktor eksternal meliputi kondisi fisik, sosial, psikologi keluarga, sekolah, serta masyarakat. Semua faktor dapat berpengaruh terhadap perkembangan siswa baik pengaruh positif ataupun negatif.

Salah satu faktor internal adalah kemampuan awal siswa yang merupakan dasar bagi siswa dalam mengembangkan potensi yang ada pada diri siswa tersebut. Kemampuan awal merupakan tolok ukur dari keberhasilan kegiatan belajar dan pembelajaran. Oleh karena itu, kemampuan awal memegang peranan penting dalam proses belajar siswa. Kemampuan seseorang yang diperoleh dari pelatihan selama hidupnya, dan apa yang dibawa untuk menghadapi suatu pengalaman baru. Kemampuan awal prasyarat awal untuk mengetahui adanya perubahan [3].

Kemampuan awal siswa ditentukan dengan memberikan tes awal. Kemampuan awal siswa ini penting bagi pendidik agar dapat memberikan dosis pelajaran yang tepat, tidak terlalu sukar dan tidak terlalu mudah.Kemampuan awal juga berguna untuk mengambil langkah-langkah yang diperlukan.

Kemampuan awal dan karakteristik siswa adalah pengetahuan dan keterampilan yang relevan, termasuk di dalamnya latar belakang informasi karakteristik siswa yang telah ia miliki pada saat mulai mengikuti suatu program pengajaran [8]. Kemampuan awal lebih rendah dari pada kemampuan baru dalam pembelajaran, kemampuan awal merupakan prasyarat yang harus dimiliki siswa 
sebelum memasuki pembelajaran materi pelajaran berikutnya yang lebih tinggi. Jadi seorang siswa yang mempunyai kemampuan awal yang baik akan lebih cepat memahami materi dibandingkan dengan siswa yang tidak mempunyai kemampuan awal dalam proses pembelajaran

Kemampuan awal merupakan langkah penting di dalam proses belajar, dengan demikian setiap pendidik perlu mengetahui tingkat kemampuan awal yang dimiliki para siswa. Dalam proses pemahaman, kemampuan awal merupakan faktor utama yang akan mempengaruhi pengalaman belajar bagi para siswa. Dari berbagai penelitian terungkap bahwa lingkungan belajar memerlukan suasana stabil, nyaman dan familiar atau menyenangkan. Lingkungan belajar, dalam konteks kemampuan awal, harus memberikan suasana yang mendukung keingintahuan siswa, semangat untuk meneliti atau mencari sesuatu yang baru, bermakna, dan menantang.

\section{METODE PENELITIAN}

Penelitian ini ingin mengkaji pengaruh waktu belajar terhadap kemampuan koneksi matematika dengan mengontrol kemampuan awal siswa. Hal ini dilakukan dengan menggunakan pendekatan kuantitatif, dimana penelitian mengkaji fakta-fakta yang terjadi. Penelitian ini berusaha memaparkan pengaruh faktor-faktor atau berbagai variabel yang mempengaruhi keadaan tanpa memanipulasi variabel tersebut. Untuk mencapai tujuan penelitian, peneliti menggunakan metode penelitian kuantitatif. Penelitian ini menempatkan kemampuan koneksi matematika sebagai variabel terikat, waktu belajar sebagai variabel bebas $1\left(\mathrm{X}_{1}\right)$ kategorikal dan kemampuan awal sebagai variabel bebas $2\left(\mathrm{X}_{2}\right)$ kovariat. Data yang diperoleh akan dianalisis dengan statistik deskriptif dan Analisis kovarian (ankova). Populasi pada penelitian ini adalah seluruh siswa reguler kelas XI IPA yang terdaftar mengikuti mata pelajaran Matematika pada semester genap 2017/2018 di SMA Bogor Center School. Sedangkan sampel sebanyak 40 orang siswa dengan rincian masing-masing kelompok penelitian 20 orang.

Teknik pengambilan sampel dalam penelitian didasarkan pada teknik multi stage random sampling, sebanyak 3 stage (tahap), yaitu : tahap pertama memilih kelompok belajar (pada penelitian ini, yang dipilih kelompok belajar reguler), tahap kedua memilih kelas (rombongan belajar), dan tahap ketiga memilih subjek penelitian (siswa). Untuk memperoleh data tersebut di atas diperlukan teknik atau metode pengumpulan data agar data yang diperoleh relevan atau ada hubungannya dengan masalah penelitian. Adapun metode atau teknik pengumpulan data diantaranya adalah angket, wawancara atau interview, pengamatan atau observasi, ujian atau tes dan dokumentasi. Berdasarkan teori tersebut, maka teknik atau metode pengumpulan data pada penelitian ini adalah menggunakan teknik tes. Sedangkan instrumen yang dipergunakakan dalam penelitian ini adalah menggunakan skala interval untuk memperoleh data mengenai pemahaman konsep Kewirausahaan dengan menggunakan tes berbentuk uraian.

\section{HASIL DAN PEMBAHASAN}

Penelitian ini terdiri dari tiga variabel yaitu kemampuan koneksi matematika sebagai variabel terikat, waktu belajar sebagai variabel bebas kategori dibedakan menjadi waktu belajar pagi dan siang. Variabel ketiga yaitu variabel bebas kovariat adalah kemampuan awal. Dari hasil analisis data penelitian yang telah dilakukan melalui tes kemampuan awal dan tes kemampuan koneksi matematika diperoleh data. Berikut ini disajikan hasil analisis deskripsi data.

Hasil analisa dari kemampuan awal kelompok siswa yang belajar di pagi hari, didapat skor rata-rata 58,40 dengan standar deviasi 18,77., median 62,50, modus 70, skor minimun 20 dan maksimum 80. Sedangkan kemampuan awal kelompok siswa yang belajar di siang hari didapatkan didapat skor rata-rata 58,75 dengan standar deviasi 12,126., median 55, modus 55, skor minimun 35 dan maksimum 85 .

Kemampuan Koneksi Matematika Kelas Pagi dan Kelas Siang. Hasil analisa dari kemampuan koneksi matematika kelompok siswa yang belajar di pagi hari didapat skor rata-rata 80,40 dengan standar deviasi 8,72, median 80, modus 80, skor minimun 65 dan maksimum 96. Sedangkan kemampuan koneksi matematika kelompok siswa yang belajar di siang hari didapat skor rata-rata 73,50 dengan standar deviasi 10,77 , median 75 , modus 75 , skor minimun 50 dan maksimum 90.

\section{Uji Normalitas}

Persyaratan dalam menganalisis data yang pertama dilakukan adalah uji normalitas, uji ini dilakukan untuk mengetahui normal tidaknya distribusi data yang akan dianalis. Berikut ini hasil dari uji normalitas.

Dari tabel 5 di atas, terlihat bahwa nilai sig kemampuan awal $(0,725>0,05)$ dan kemampuan koneksi matematika $(0,331>0,05)$ yang artinya data dari semua variabel berdistribusi normal.

\section{Uji Homogenitas}

Uji Homogenitas dilakukan untuk mengetahui bahwa antara kelompok siswa yang belajar Matematika di pagi hari (A1) dan kelompok siswa yang belajar Matematika di siang hari (A2) memiliki varians yang sama. Hasil analisis dapat dilihat pada tabel 2 .

Hasil analisis dan pengujian homogenitas dengan Levene's Test diperoleh hasil nilai $\mathrm{F}=0,050$ dengan nilai sig $=0,825>0,05$, sehingga 
disimpulkan bahwa antara kelompok siswa yang belajar Matematika di pagi hari (A1) dan kelompok siswa yang belajar Matematika di siang hari (A2) memiliki varians yang sama.

\section{Uji Linearitas}

Uji linearitas dilakukan untuk mengetahui kelinearan regresi kovariat $(\mathrm{X})$ terhadap variabel terikat $(\mathrm{Y})$. Nilai sig adalah bilangan yang tertera pada kolom sig baris Deviation from Linierity dalam tabel ANOVA.

Berdasarkan tabel 3 diperoleh bahwa nilai signifikansi pada Deviation from Linearity sebesar 0,313 . Karena signifikansi > 0,05 maka dengan demikian dapat disimpulkan bahwa variabel kovariat (kemampuan awal) (X) terhadap variabel kemampuan koneksi matematika (Y) terdapat hubungan linear.

\section{Uji Hipotesis Penelitian}

Hipotesis pertama yang diuji yaitu terdapat perbedaan rerata kemampuan koneksi Matematika antara kelompok yang belajar Matematika di pagi hari dengan kelompok yang belajar di siang hari, setelah mengontrol kemampuan awal siswa.

Berdasarkan tabel di atas, diperoleh untuk baris kelompok nilai $\mathrm{F}=6,264$ dengan nilai sig. $=$ $0,017<0,05$; sehingga disimpulkan bahwa terdapat perbedaan rarata kemampuan koneksi matematika siswa yang signifikan menurut faktor waktu belajar dengan mengontrol kemampuan awal Matematika siswa. Dengan demikian dapat disimpulkan terdapat pengaruh waktu belajar terhadap kemampuan koneksi matematika setelah mengontrol pengaruh kemampuan awal Matematika siswa.

Hipotesis kedua yang diuji yaitu: Diduga bahwa rerata kemampuan koneksi matematika antara kelompok siswa yang belajar Matematika di pagi hari lebih tinggi daripada kelompok siswa yang belajar di siang hari.

Tabel 1. Uji Normalitas

One-Sample Kolmogorov-Smirnov Test

\begin{tabular}{|ll|r|r|}
\hline & & $\begin{array}{r}\text { Kemampuan_ } \\
\text { Awal }\end{array}$ & $\begin{array}{r}\text { Kemampuan_Koneksi } \\
\text { _Matematika }\end{array}$ \\
\hline $\mathrm{N}$ & & 40 & 40 \\
Normal & Mean & 58,58 & 76,95 \\
Parameters & Std. Deviation & 15,597 & 10,286 \\
Most & Absolute &, 109 &, 150 \\
Extreme & Positive &, 066 &, 067 \\
Differences & Negative &,- 109 &,- 150 \\
Kolmogorov-Smirnov Z &, 692 &, 948 \\
Asymp. Sig. (2-tailed) &, 725 &, 331 \\
\hline
\end{tabular}

a. Test distribution is Normal.

b. Calculated from data.

Tabel 2. Hasil Pengujian Homogenitas Levene's Test of Equality of Error Variances ${ }^{a}$

Dependent

Variable:Kemampuan_Koneksi_Matematika

\begin{tabular}{|c|c|c|c|}
\hline $\mathrm{F}$ & df1 & df2 & Sig. \\
\hline, 050 & 1 & 38 &, 825 \\
\hline
\end{tabular}

Tabel 3. Hasil Test for Linearity Variabel Kovariat (Kemampuan Awal) terhadap Kemampuan koneksi matematika

ANOVA Table

\begin{tabular}{|lll|r|r|r|r|r|}
\hline & & Sum of Squares & Df & Mean Square & F & Sig. \\
\hline Kemampu & Between & (Combined) & 1875,021 & 12 & 156,252 & 1,874 &, 086 \\
an_Konek & Groups & Linearity & 743,043 & 1 & 743,043 & 8,913 &, 006 \\
si_Matem & & Deviation from & 1131,979 & 11 & 102,907 & 1,234 &, 313 \\
atika $*$ & & Linearity & & & & \\
Kemampu & Within Groups & & 2250,879 & 27 & 83,366 & & \\
an_Awal & Total & & 4125,900 & 39 & & & \\
\hline
\end{tabular}


Tabel 4. Hasil Analisis untuk Pengujian Hipotesis tentang Perbedaan Rerata Y Menurut Faktor Kelompok (Waktu belajar) dengan Mengontrol Kemampuan Awal.

Tests of Between-Subjects Effects

Dependent Variable:Kemampuan_Koneksi_Matematika
\begin{tabular}{|l|r|r|r|r|r|}
\hline Source & Type III & & & & \\
& Sum of & & Mean & & \\
& Squares & df & Square & \multicolumn{1}{c|}{ F } & \multicolumn{1}{c|}{ Sig. } \\
\hline Corrected Model & $1232,819^{a}$ & 2 & 616,409 & 7,883 &, 001 \\
Intercept & 9436,793 & 1 & 9436,793 & 120,688 &, 000 \\
Kelompok & 489,776 & 1 & 489,776 & $\mathbf{6 , 2 6 4}$ &, $\mathbf{0 1 7}$ \\
Kemampuan_Awal & 756,719 & 1 & 756,719 & 9,678 &, 004 \\
Error & 2893,081 & 37 & 78,191 & & \\
Total & 240978,000 & 40 & & & \\
Corrected Total & 4125,900 & 39 & & & \\
\hline
\end{tabular}

a. R Squared = ,299 (Adjusted R Squared = ,261)

Tabel 5. Parameter Estimasi untuk Pengujian Hipotesis tentang Perbedaan Rerata Y Menurut Faktor A dengan Mengontrol X dengan Uji Satu Pihak

\begin{tabular}{|c|c|c|c|}
\hline Parameter & Std. Error & T & Sig. \\
\hline Kemampuan koneksi matematika & 3,099 & 2,226 & 0,032 \\
\hline
\end{tabular}

Berdasarkan tabel di atas, diperoleh nilai $\mathrm{t}$ $=2,226$ dengan nilai sig. $0,032<0,05$, sehingga disimpulkan bahwa kemampuan koneksi matematika siswa yang belajar di pagi hari secara signifikan lebih tinggi dari pada siswa yang belajar di siang hari, setelah mengontrol kemampuan awal siswa.

Penelitian ini secara umum bertujuan untuk memperoleh gambaran lebih lengkap tentang pengaruh waktu belajar terhadap kemampuan koneksi matematika dengan mengontrol kemampuan awal siswa. Hasil penelitian menunjukkan bahwa variabel waktu belajar mempunyai pengaruh yang signifikan terhadap kemampuan koneksi matematika setelah mengontrol kemampuan awal. Hasil yang diperoleh menunjukkan rerata kemampuan koneksi matematika siswa yang belajar di pagi hari sebesar 80,40 dan rerata kemampuan koneksi matematika siswa yang belajar di siang hari sebesar 73,50.

Dalam penelitian ini yang dimaksud dengan kemampuan koneksi matematika yaitu hasil belajar Matematika kelas XI pada pokok bahasan limit fungsi dan turunan fungsi. Materi tersebut merupakan kelanjutan dari pelajaran Matematika di kelas VIII atau kelas IX sekolah menengah pertama. Penguasaan materi komposisi fungsi akan sangat berpengaruh terhadap pemahaman materi limit fungsi dan turunan fungsi yang dipelajari pada materi semester 1. Penguasaan limit fungsi merupakan pengetahuan prasyarat yang harus dimiliki siswa sebelum mempelajari turunan fungsi.
Faktor perbedaan waktu belajar dimaksudkan untuk memberikan gambaran tentang pengaruh pelaksanaan kegiatan belajar terhadap kemampuan koneksi matematika. Waktu belajar yang dimaksud adalah pelaksanaan kegiatan pembelajaran Matematika yaitu (1) pagi hari pukul 07.1508.55, dan (2) siang hari pukul 12.30-14.10. Pembelajaran merupakan waktu terjadinya proses belajar-mengajar di sekolah, waktu belajar di sekolah dapat pagi dan siang hari [4]. Demikian pula kondisi waktu belajar di SMA Bogor Center School.

Matematika merupakan salah satu mata pelajaran yang dianggap sulit oleh siswa, karena untuk memahaminya memerlukan konsentrasi yang tinggi [9]. Oleh karena itu, efektif tidaknya materi Matematika diterima oleh siswa juga dipengaruhi oleh waktu belajar Matematika di kelas XI. Kegiatan belajar Matematika di pagi hari tentu saja akan mudah diserap siswa, karena pikiran siswa masih segar dan belum jenuh. Pengaruh yang signifikan waktu belajar terhadap hasil belajar matematika siswa [10]. Kondisi waktu pagi hari yang masih segar karena belum banyak beraktifitas membantu siswa konsentrasi dalam belajar.

Udara yang masih bersih dan hangatnya sinar matahari di pagi hari memberikan semangat bagi siswa untuk belajar. Pembelajaran pukul 07.00 - 10.00 adalah jam pertama pembelajaran di SMA Bogor Center School. Oleh karena itu, siswa yang mengikuti pembelajaran pada waktu tersebut dalam kondisi yang siap sedia untuk menerima materi pelajaran dengan baik. Kendala yang dihadapi pada pembelajaran di pagi hari adalah terdapat beberapa 
siswa yang datang terlambat mengikuti pembelajaran.

Kegiatan pembelajaran Matematika dasar yang dilaksanakan di siang hari kemungkinan besar materi yang dapat diserap siswa lebih sedikit, karena jasmani maupun rohani siswa sudah lelah dan jenuh sehingga sulit berkonsentrasi. Pembelajaran pukul 10.00-15.30 merupakan waktu yang kurang efektif untuk menerima materi pelajaran dengan baik, karena sebelumnya siswa telah mengikuti pembelajaran mata pelajaran sebelumnya maupun aktivitas lainnya. Udara siang yang tidak sebagus udara di pagi hari menciptakan suasana belajar yang kurang kondusif. Oleh karena itu, kondisi siswa pada siang hari hanya memiliki sisa tenaga dan pikiran yang tidak optimal untuk menerima materi pelajaran dengan baik. Hal ini ditunjukkan dari skor minimum kemampuan koneksi matematika siswa yang belajar di siang hari lebih rendah daripada skor minimum kemampuan koneksi matematika siswa yang belajar di pagi hari.

Berdasarkan penjelasan tersebut, maka dapat dipahami bahwa secara keseluruhan waktu belajar di pagi hari akan lebih baik daripada waktu belajar di siang hari dalam proses pembelajaran Matematika.

\section{KESIMPULAN \\ Kesimpulan}

Terdapat perbedaan rerata kemampuan koneksi matematika antara kelompok yang belajar di pagi hari dengan kelompok yang belajar di sore hari, setelah mengontrol kemampuan awal mahasiswa. Dalam hal ini rerata kemampuan koneksi matematika kelompok siswa yang belajar di pagi hari lebih tinggi dari pada kelompok siswa yang belajar di sore hari, setelah mengontrol kemampuan awal siswa.

\section{DAFTAR PUSTAKA}

[1] Turmuzi, M., Sripatmi, S., Azmi, S., \& Hikmah, N. (2018). PENERAPAN MODEL PEMBELAJARAN CREATIVE PROBLEM SOLVING (CPS) UNTUK MENINGKATKAN KEMAMPUAN PEMECAHAN MASALAH MAHASISWA PENDIDIKAN MATEMATIKA. Jurnal Pijar Mipa, 13(1), 45-50.

[2] Kurniati, T., \& Kurniawan, R. A. (2017). Pengaruh Pembelajaran Kooperatif Tipe TGT dan Gaya Belajar Model vark Terhadap Hasil Belajar Kimia Sekolah Pada Mahasiswa Program Studi Pendidikan Kimia. Jurnal Pendidikan Matematika dan IPA, 8(2), 41-49.
[3] Syah, M. (1995). Psikologi pendidikan suatu pendekatan baru. Bandung: Remaja Rosdakarya.

[4] Slameto, B., \& yang Mempengaruhinya, F. F. (2003). PT Rineka Cipta.

[5] Bergeson, T., Fitton, R., \& Bylsma, P. (2000). Teaching and learning mathematics using research to shift from the "yesterday" mind to the "tomorrow" mind. Washington State, State Superintendent of Public Instruction.

[6] Graham, K. J., \& Fennell, F. (2001). Principles and standards for school mathematics and teacher education: Preparing and empowering teachers. School Science and Mathematics, 101(6), 319-327.

[7] Banihashemi, S.S.A. 2003. Connection of old and new mathematics on works of Islamic mathematician with a look to role of history of mathematics on education of mathematics. Informing science.

[8] Sudjana, N. (2003). Penilaian Hasil Proses Belajar Mengajar Cetakan Ketujuh. Bandung: PT. Remaja Rosdakarya.

[9] Hirzi, R. H., Sripatmi, S., \& Hapipi, H. (2015). Penerapan model pembelajaran kooperatif tipe snowball throwing pada pembelajaran segiempat untuk meningkatkan aktivitas dan prestasi belajar siswa smpn 1 lingsar kelas vii-1 tahun pelajaran 2012/2013. Jurnal pijar MIPA, 10(1).

[10] Lestari, I. (2013). Pengembangan bahan ajar berbasis kompetensi. Padang: Akademia Permata, 1. 